\title{
Crangopsis Salter, 1863 from the Lower Carboniferous (Mississippian) of the Ostrava Formation - the first record of Aeschronectida (Malacostraca: Hoplocarida) from continental Europe
}

\author{
MATÚŠ HYŽNÝ, IVAN HOCH, FREDERICK R. SCHRAM \& SAMUEL RYBÁR
}

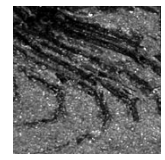

\begin{abstract}
A newly found specimen of an aeschronectid hoplocaridan Crangopsis cf. socialis (Salter, 1861) from the Lower Carboniferous (Mississippian) of the Ostrava Formation (Czech Republic) represents the first occurrence of Aeschronectida from continental Europe. The studied specimen preserves all thoracopods allowing careful description. Morphological similarities between the present material and its relative Kallidecthes richardsoni Schram, 1969 allows reassignment of Crangopsis from Aratidecthidae to Kallidecthidae, leaving the former family with only its type genus Aratidecthes. Thoracopod morphology of Crangopsis socialis based on the present material suggests an upraised posture of the animal during its life. The upraised posture might have developed independently at least twice within Hoplocarida, in Aeschronectida and Stomatopoda. The body of Crangopsis socialis, and consequently of all aeschronectids, is divided into four tagmata: the sensorial unit, the food-processing unit, the walking-appendage area, and the pleon plus tailfan in contrast to five in Stomatopoda. Key words: Hoplocarida, Aeschronectida, Crangopsis, Mississippian, the Ostrava Formation, thoracopod morphology, tagmatization.
\end{abstract}

\begin{abstract}
HYŽNÝ, M., HOCH, I., SCHRAM, F.R. \& RYBÁR, S. 2014. Crangopsis Salter, 1863 from the Lower Carboniferous (Mississippian) of the Ostrava Formation - the first record of Aeschronectida (Malacostraca: Hoplocarida) from continental Europe. Bulletin of Geosciences 89(4), 707-717 (8 figures, 2 tables). Czech Geological Survey, Prague. ISSN 1214-1119. Manuscript received June 4, 2013; accepted in revised form December 10, 2013; published online July 8, 2014; issued September 30, 2014.
\end{abstract}

\begin{abstract}
Matúš Hyžný (corresponding author), Geological-Paleontological Department, Natural History Museum Vienna, Burgring 7, A-1010 Vienna, Austria, and Department of Geology and Palaeontology, Faculty of Natural Sciences, Comenius University, Mlynská dolina G1, SK-842 15 Bratislava, Slovakia; hyzny.matus@gmail.com, matus.hyzny@nhm-wien.ac.at • Ivan Hoch, Green Gas DPB, a.s., CZ-739 21 Paskov, Czech Republic • Frederick R. Schram, Box 1567, Langley, WA 98260, USA, and Burke Museum of Natural History and Cultures, University of Washington, Seattle,WA, USA; fschram@u.washington.edu・Samuel Rybár, Department of Geology and Palaeontology, Faculty of Natural Sciences, Comenius University, Mlynská dolina G1, SK-842 15 Bratislava, Slovakia; rybar@fns.uniba.sk
\end{abstract}

Numerous hoplocaridan crustaceans (Malacostraca: Hoplocarida) have been described from Carboniferous strata (Peach 1908; Brooks 1962, 1969; Schram 1969, 1979; Schram \& Horner 1978; F.R. Schram \& J.M. Schram 1979; J.M. Schram \& F.R. Schram 1979; Jenner et al. 1998; Schöllman 2004); in some cases they can attain great densities and be a major element of the macrofauna (Schram 1983, Schöllman 2004). Hoplocaridans were already diversified in the Carboniferous (Lange \& Schram 1999) with at least two independent lineages, i.e., stomatopods (mantis shrimps) and aeschronectidans. Representatives of Aeschronectida have been reported so far only from the Carboniferous strata of the United States (Schram 1969, F.R. Schram \& J.M. Schram 1979, J.M. Schram \& F.R. Schram 1979, Jenner et al. 1998) and the British Isles (Peach 1908, Schram 1979). Present material identified as Crangopsis cf. socialis
(Salter, 1861) is the first occurrence of Aeschronectida from continental Europe. Although several detailed studies were dedicated to aeschronectids (Schram 1969, 1979; Schram \& Horner 1978; J.M. Schram \& F.R. Schram 1979; see also Watling et al. 2000), their functional morphology is poorly understood. This contribution provides new data on the morphological details of the body parts previously not reported in Crangopsis Salter, 1863, and discusses the mode of life of kallidecthid aeschronectidans.

\section{Geological settings}

The studied specimen comes from the middle part of the Poruba Member of the Ostrava Formation in the Upper Silesian Coal Basin, Czech Republic (Fig. 1). The Upper 

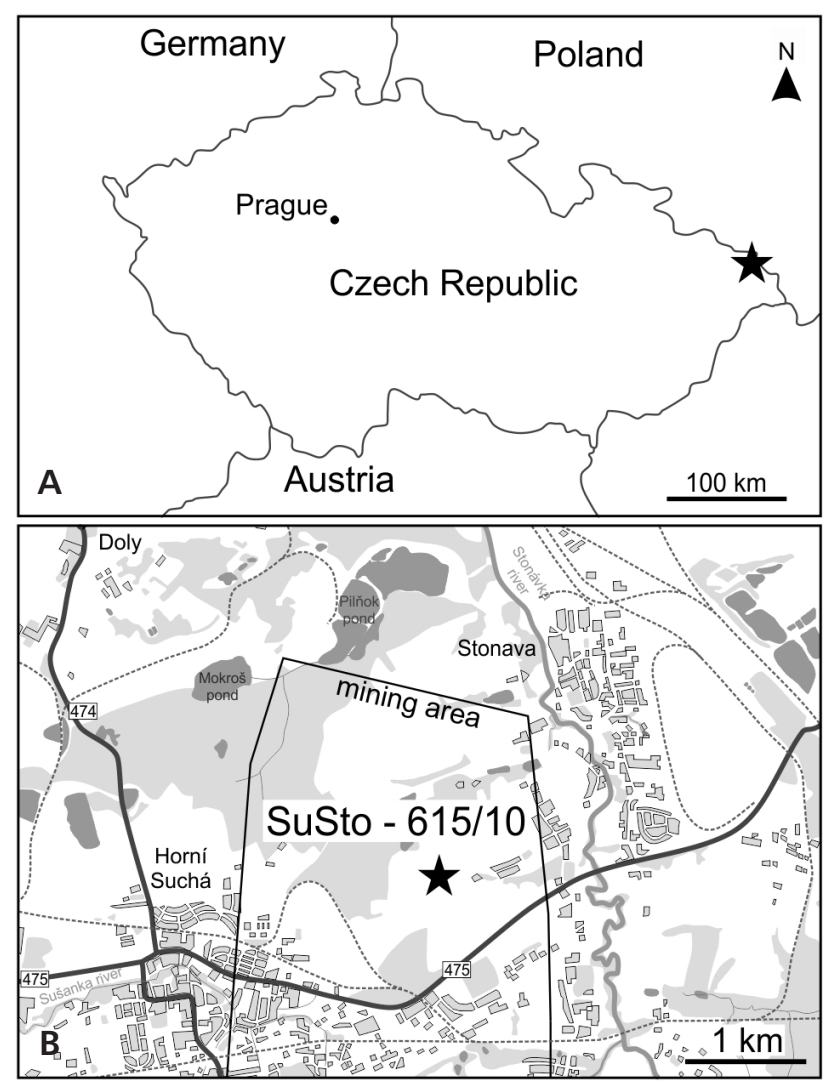

Figure 1. Locality of the well SuSto-615/10. A - geographical position of the area of mine Darkov in NE Czech Republic. - B - the area of the mine with the locality of the well SuSto-615/10.

Silesian Basin is a foreland formed during the late Palaeozoic as part of the European Variscan fold belt and lies at the eastern margin of the Variscan Bohemian Massif (Dopita \& Kumpera 1993, Gastaldo et al. 2009). The Ostrava Formation consists of cyclical coal-bearing continental and fossiliferous marine deposits of a paralic nature (Havlena 1986, Dopita \& Kumpera 1993). It is subdivided stratigraphically into several units, with the Poruba Member being the youngest.

The specimen comes from the mesocycle f.h. Lotara, the horizon XXV, goniatite Subzone $E_{2 b}$, the upper phytostratigraphic zone of the early Namurian ( ̌̌ehoř \& Řehořová 1972). It occurs in a well core $(74.9 \mathrm{~m})$ of the SuSto-615/10 (Darkov mine; Fig. 1B) above coal seam No. 454 of the $\log$ (Fig. 2). A shallow marine palaeoenvironment has been interpreted for this sedimentary sequence. Lithologically it is composed of dark-grey siltstones attaining a thickness of approximately 8 meters. About 5 meters above coal seam No. 454, fragmentary remains of gastropods (Glabrocingulum sp.) and brachiopods (Ambocoelia sp.) have been found. The studied aeschronectid comes from the uppermost part of this bed (Fig. 2).

Higher in the section marine sedimentation gives way

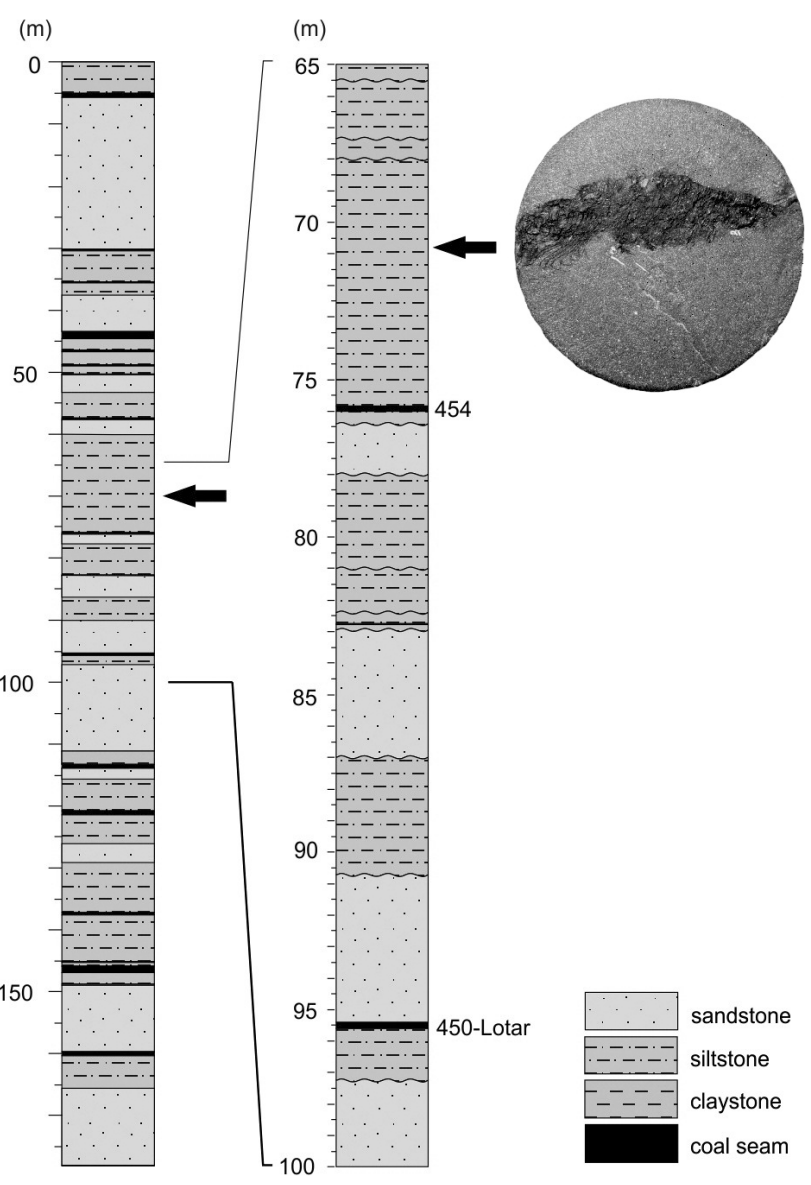

Figure 2. Well-core SuSto-615/10. Lithological scheme of the core up to $c a 180 \mathrm{~m}$ depth. The position of the studied Crangopsis specimen is indicated with a black arrow. The photograph shows dry and uncoated specimen OM B 13970.

to fresh water sediments composed of siltstones with plant debris and alternating fine grained light-gray sandstones. In the siltstones, fresh-water ostracodes, polychaetes (Spirorbis sp.) and bivalves (Naiadites truemani) have been found. Fresh-water sedimentation has been documented also $7 \mathrm{~m}$ below coal seam No. 454, specifically above coal seam No. 452. Bivalves Porubites lotari (̌̌ehoř, 1965) and N. truemani have been reported from this part of the section.

\section{Material and methods}

The material consists of a single laterally compressed and flattened specimen (OM B 13970) composed of part and counterpart (Fig. 3). Compression and flattening is quite typical for aeschronectid hoplocaridans (see Peach 1908; Schram 1969, 1979). The specimen is fairly complete, but because the shield is damaged its exact shape is uncertain. Because it was retrieved from a well core the probability of collecting a second specimen is remote. 

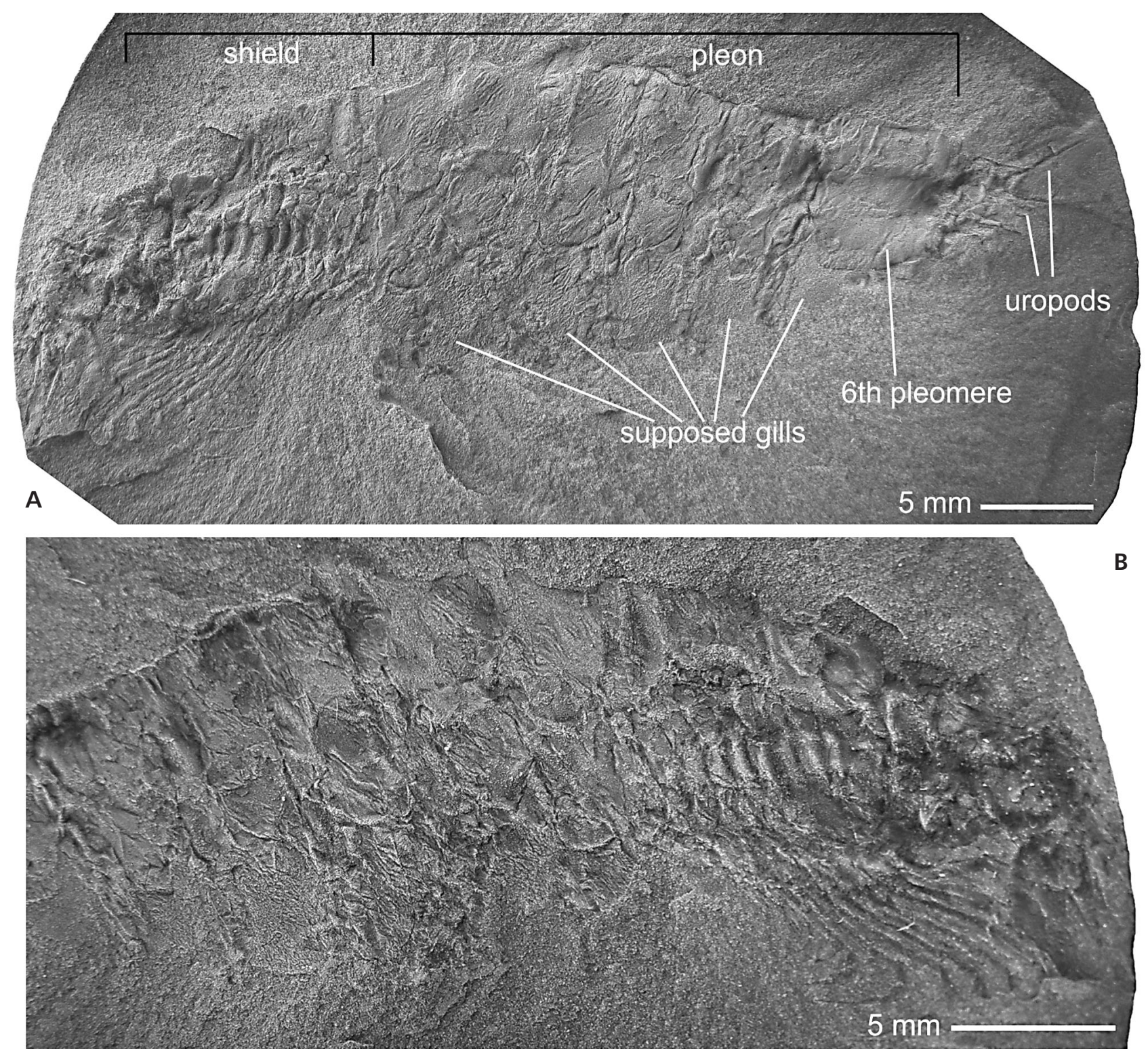

Figure 3. Crangopsis cf. socialis (Salter, 1861). The studied specimen (OM B 13970) consisting of part (A) and counterpart (B). The specimen was coated with ammonium chloride prior the photography.

The fossil was studied using stereomicroscope Leica EZ4. It was photographed using several different methods: (1) dry, (2) under alcohol, and (3) coated with ammonium chloride. Photographs were made with an Olympus SP-510UZ camera. Interpretative drawings were prepared using Corel Graphics Suite software. All measurements are in millimeters.

Following Haug et al. (2012) we use the term "shield" instead of "carapace". For exhaustive discussion on usage of these terms a reference is made to Walossek (1993). For the basal thoracopod elements we use terms precoxa, coxa and basis. See Haug et al. (2013) for a different view.

Repositories. - Ostrava Museum in Ostrava, Czech Republic (OM).

\section{Systematic palaeontology}

Class Malacostraca Latreille, 1802

Subclass Hoplocarida Calman, 1904

Order Aeschronectida Schram, 1969

Remarks. - Hoplocarida has two daughter taxa: Stomatopoda (including all modern representatives in Unipeltata) and Aeschronectida (Schram 1986, Watling et al. 2000, Schram et al. 2013 and references therein). Both sister taxa are given order status (Jenner et al. 1998, Watling et al. 2000, Schram 2007). The latter are represented by a handfull of genera within three families: Aenigmacarididae Schram \& Horner, 1978, Aratidecthidae Schram, 1979, 
Table 1. Overview of the currently recognized aeschronectid species in the literature.

\begin{tabular}{ll}
\hline TAXON & DISTRIBUTION \\
\hline Aenigmacarididae & \\
\hline Aenigmacaris cornigerum Schram \& Horner, 1978 & Mississippian - USA (Montana) \\
Aenigmacaris minima F.R. Schram \& J.M. Schram, 1979 & Pennsylvanian - USA (New Mexico) \\
Joanellia elegans Schram, 1979 & Mississippian - UK (Scotland, N England) \\
Joanellia lundi J.M. Schram \& F.R. Schram, 1979 & Mississippian - USA (Montana) \\
\hline Aratidecthidae & \\
\hline Aratidecthes johnsoni Schram, 1969 & Pennsylvanian - USA (Indiana) \\
\hline Kallidecthidae & \\
\hline Crangopsis eskdalensis (Peach, 1882) & Mississippian - UK (Scotland, N England), USA (Illinois) \\
Crangopsis socialis (Salter, 1861) & Mississippian - UK (Scotland, N England) \\
Crangopsis cf. socialis (Salter, 1861) & Mississippian - Czech Republic (herein) \\
Kallidecthes eagari Schram, 1979 & Pennsylvanian - UK (Scotland, N England) \\
Kallidecthes richardsoni Schram, 1969 & Pennsylvanian - USA (Illinois) \\
\hline
\end{tabular}

and Kallidecthidae Schram, 1969 (Table 1). Their anterior and pleon morphology is based on relatively wellpreserved specimens from several localities of the Mississippian of the United States (Schram 1969, J.M. Schram \& F.R. Schram 1979) and Middle Pennsylvanian of Scotland (Peach 1908, Schram 1979). The morphology of the thoracopods and other appendages is rather obscure; wellpreserved thoracopods have been so far described only in Kallidecthes richardsoni Schram, 1969 (Schram 1969, Watling et al. 2000). Although Peach (1908) described appendages also for Crangopsis socialis (Salter, 1861), details of distal elements are not clearly visible (FRS, personal observations) in the published figures and restorations are idealized.

Family Kallidecthidae Schram, 1969

\section{Genus Crangopsis Salter, 1863}

Type species. - Uronectes socialis Salter, 1861.

Remarks. - Schram (1979) considered Crangopsis to be a close relative of Aratidecthes Schram, 1969 and classified both genera within Aratidecthidae. He noted that comparison of the thoracopods was difficult because of the taphonomy of all species of Crangopsis known to that date. The new material presented herein exhibits parts that are reported in Crangopsis for the first time and allows re-assessment of the systematic affinities of the genus. Because of close morphological affinities in the general organization of the body (ratio of the anterior body portion and pleon) and nature of thoracopods (number of elements, thoracopod shortening posteriorly) we re-assign Crangopsis to Kallidecthidae.

It should be noted that the reconstruction of Crangopsis socialis refigured in several Slovak and Czech palaeontology textbooks (Houša in Špinar et al. 1965, fig. X-148; Švagrovský 1976, fig. IX-103) comes from the monograph by Peach (1908) and is based on the specimens from the Carboniferous of Scotland. Peach's reconstruction, however, is idealized (compare with more accurate reconstruction of Crangopsis made by Brooks 1969, fig. 155A).

\section{Crangopsis cf. socialis (Salter, 1861)}

Figures 3-8

1861 Uronectes socialis Salter, p. 394, fig. 2.

1979 Crangopsis socialis (Salter). - Schram, p. 40, figs 9a, 10; cum syn. (1861-1969).

Material. - A single near-complete specimen (part and counterpart; deposited under OM B 13970) from the well core SuSto-615/10 (the Darkov mine, 74.9 m); Mississippian (Lower Namurian) of the Poruba Beds of the Ostrava Formation, Czech Republic. See Table 2 for the measurements.

Description. - The shrimp-like body is laterally compressed. The cuticle apparently was poorly sclerotized; the entire surface is wrinkled. The subtrapezoidal carapace (in lateral view) is poorly preserved. Traces of the base of an eye stalk are present.

The fusiform pleon is approximately twice the length of the shield. The second pleomere is longer than the first one; the third pleomere is distinctly shorter than the second one, the fourth-fifth pleomeres are longer than the third one; the sixth pleomere is the longest. The margin of tergopleuron of the second pleomere is rounded; those of the third to fifth are most probably triangular in outline with rounded corners (Fig. 4D). Telson is poorly preserved. 

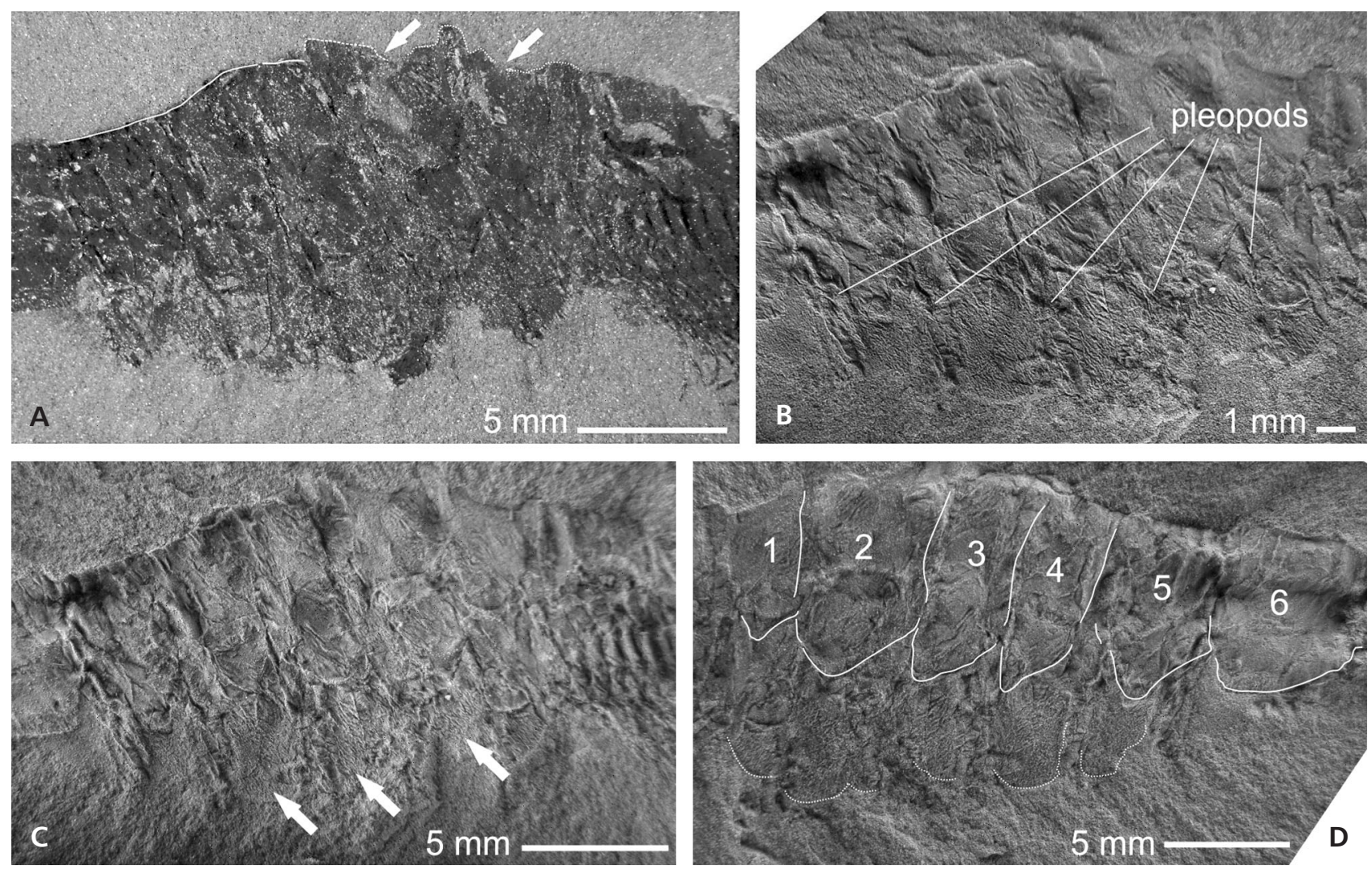

Figure 4. Crangopsis cf. socialis (Salter, 1861), OM B 13970. Pleonal segments. The dorsal outline of the pleomeres is well preserved only in the posterior segments (A - arrows show damaged outline). Pleopods are simple (B) with preserved supposed gills (white arrows in C), their outline is rounded (dotted line in D). A-C = OM B 13970 counterpart, D = OM B 13970 part. A depicts the specimen under alcohol, whereas in B, C and D the specimen was coated with ammonium chloride prior the photography.
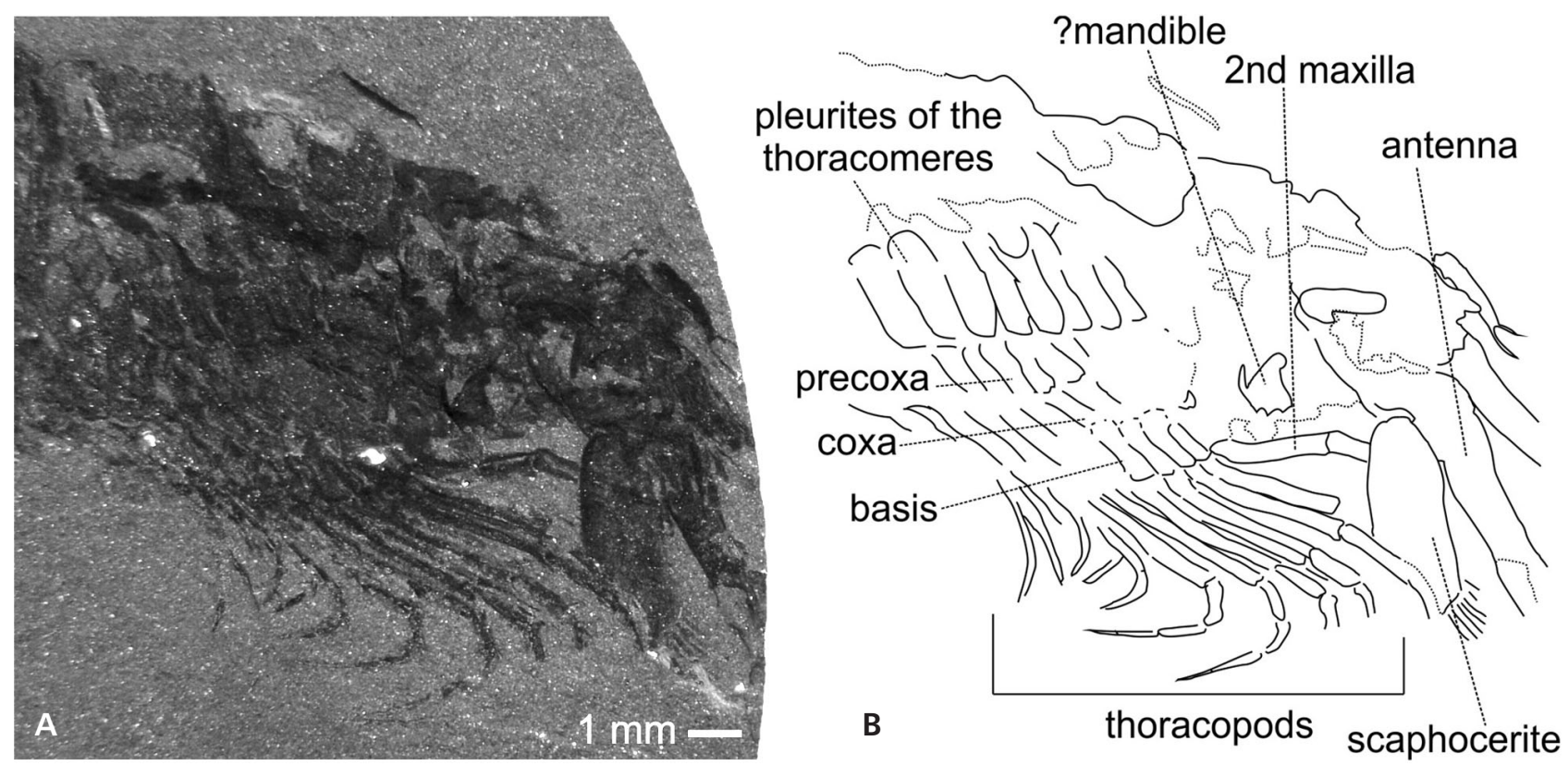

Figure 5. Crangopsis cf. socialis (Salter, 1861), OM B 13970. Head and thorax with appendages. • A - under alcohol, B - interpretive line drawing. 
A
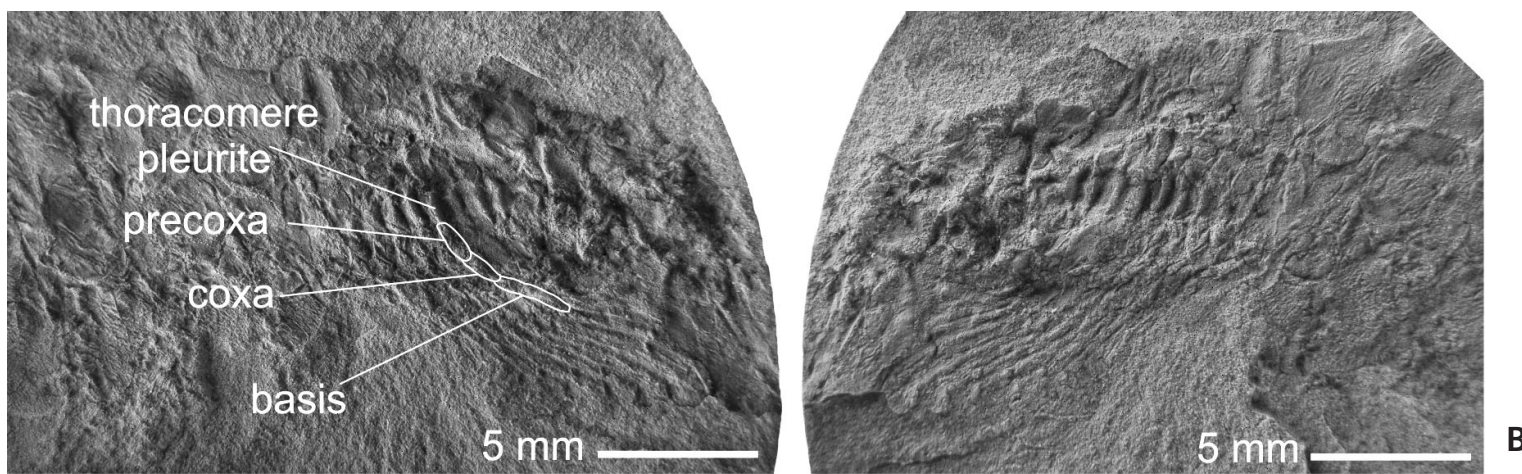

\section{B}
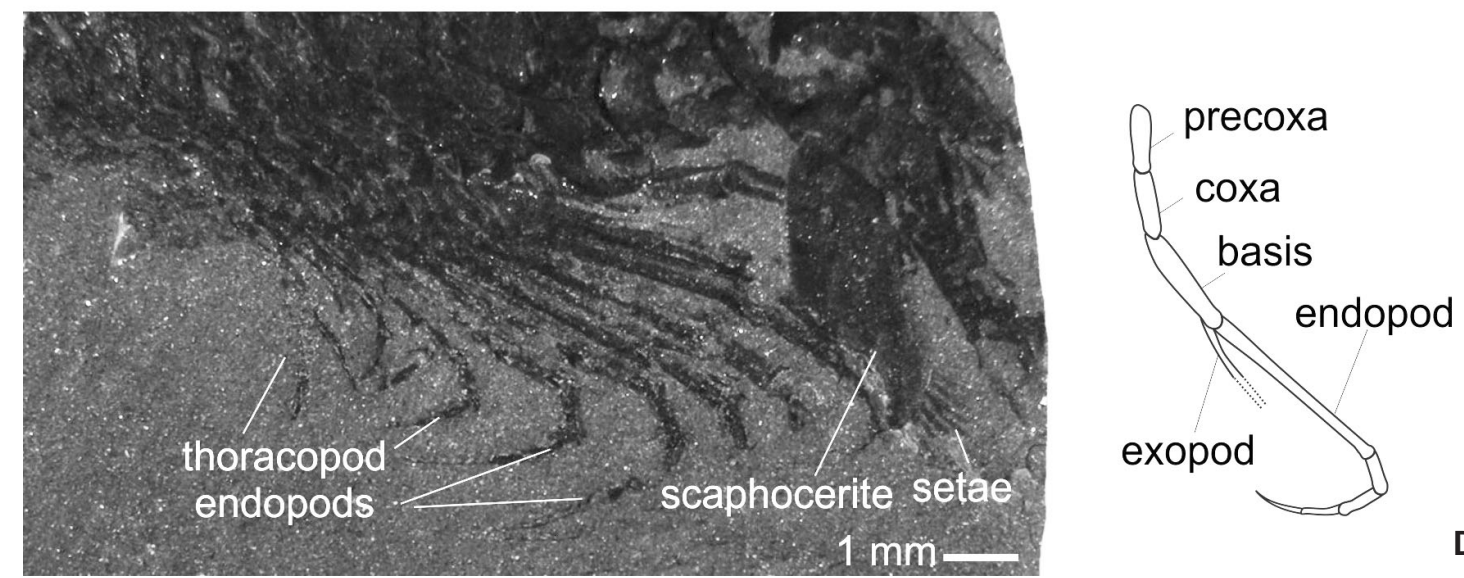

Figure 6. Crangopsis cf. socialis (Salter, 1861), OM B 13970. Thoracopods. Part (A) and counterpart (B) show well preserved thoracopods including basal segments (precoxa, coxa, basis). Note the presence of setae on scaphocerite (C). D represents a scheme of reconstructed thoracopod; morphological details of the inner branch are obscured. A, B were coated with ammonium chloride prior the photography, C was photographed under alcohol.

Table 2. Measurements (in mm) of the studied specimen (OM B 13970) of Crangopsis cf. socialis (Salter, 1861).

\begin{tabular}{lcccccccc}
\hline \multirow{2}{*}{ Specimen } & Shield $\begin{array}{c}\text { Total } \\
\text { pleon }\end{array}$ & \multicolumn{5}{c}{ Pleonal segments } \\
\cline { 3 - 9 } & & & 1 & 2 & 3 & 4 & 5 & 6 \\
\hline OM B 13970 & $c a 10$ & 19.7 & 2.5 & 4.0 & 2.3 & 3.1 & 3.5 & 4.3 \\
\hline
\end{tabular}

Appendages are moderately well preserved. Antennal elements are robust. The scaphocerite (a distal flattened plate of antennal exopod) is oval, about three times longer than broad, with setae; distal end is not preserved. What appears to be the mandible is insufficiently preserved (Fig. 5). The second maxilla palp is long and robust.

Altogether eight thoracopod pairs are present; right and left leg series are preserved as partially superimposed. Thoracopods are progressively shorter toward the pleon, the anteriormost thoracopod being the longest and posteriormost the shortest. Although the preservation is not superb, virtually all thoracopod elements are recognized; precoxa and coxa, although concealed by shield, are visible and are of similar length, the basis is slightly longer (Fig. 6A). Precoxae are attached to pleurites of the thoracomeres on the body wall. Seemingly, both outer and inner thoracopod branches are preserved; the outer branch ("exopod") is distinctly shorter (Fig. 6D), presumably consisting of a single element; the inner branch ("endopod") consists of five elements.

Pleopods are simple (uniramous paddles) (Fig. 4B) with elements oval in outline (Fig. 4D) and with elaborate structures on the surface (Fig. 4C), interpreted here as gills. Uropods are elongate and blade-like (Fig. 7).

This description is based solely on the studied specimen.

Remarks. - The shape of the pleura points to the identification of the specimen as probably Crangopsis socialis (compare Schram 1979, fig. 9). Interestingly, the third to fifth pleomeres are increasingly longer toward the telson, whereas in Crangopsis socialis from the Carboniferous of Scotland and reported by Schram (1979) they are increasingly shorter in the same direction. According to Schram (1979, tables 4, 5) the ratio of the respective pleomere lengths in species of Crangopsis, is variable and is considered a matter of intraspecific variation herein.

The identification of one of the anterior appendages as a maxilla is based on the fact that the basal inner branch thoracopod segment is distinctly longer than the respective element of the supposed maxilla (Fig. 5B). 

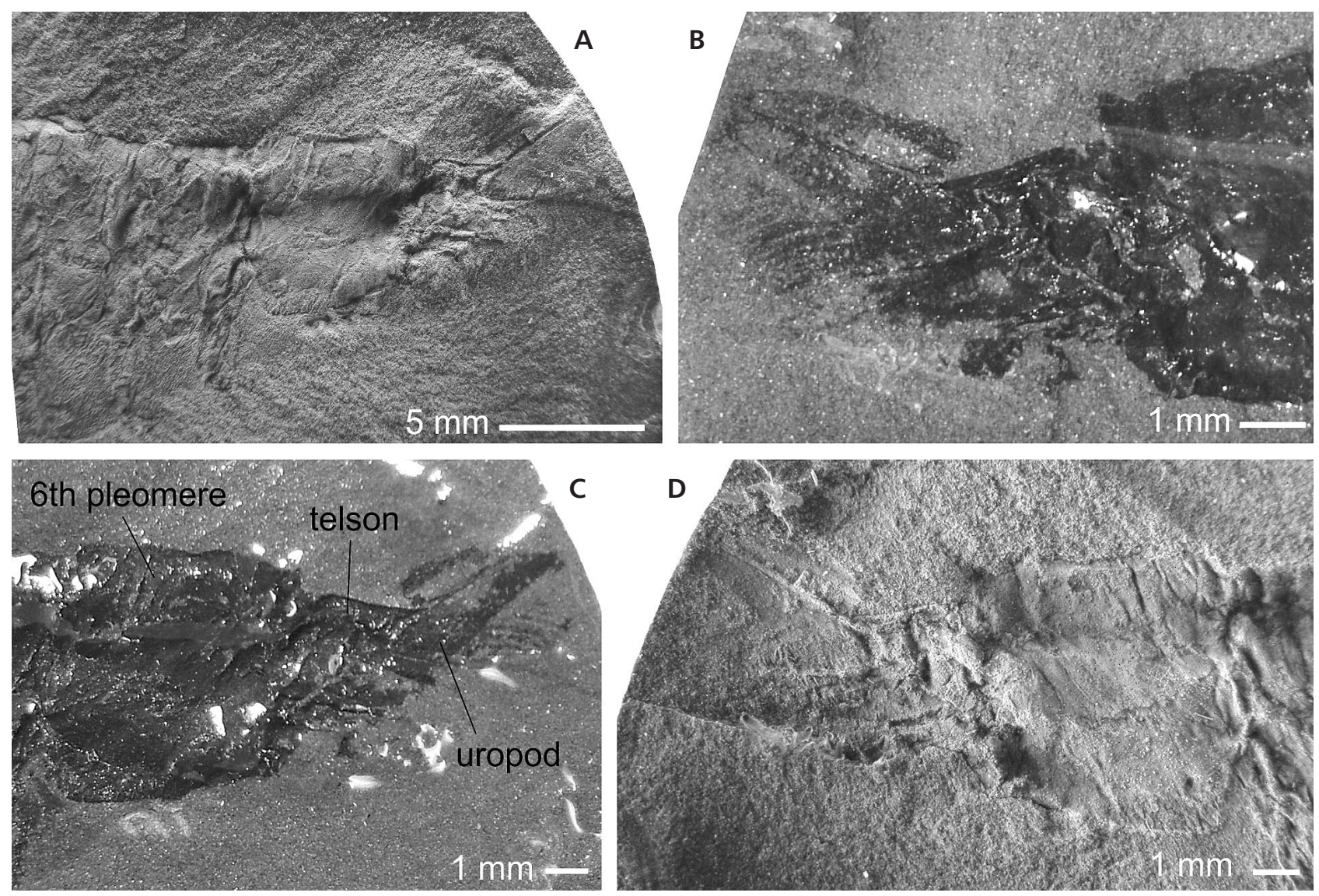

Figure 7. Crangopsis cf. socialis (Salter, 1861), OM B 13970. Telson and uropods. A and D were coated with ammonium chloride prior the photography, B, C were photographed under alcohol. A, C = part, B, D = counterpart.

The shortening of the posterior series of thoracopods in Crangopsis socialis was previously reported by Peach (1908). Such shortening is also known for its relatives Kallidecthes richardsoni and K. eagari (Schram 1969, 1979, respectively). Both genera, Crangopsis and Kallidecthes, however, differ in various aspects of the body. The carapace shield outline is subtrapezoidal in Crangopsis, whereas it is subtriangular in Kallidecthes (Schram 1979). The antennal elements and maxilla, as documented by present material, are more robust in Crangopsis (Fig. 5) than in Kallidecthes (Schram 1979, fig. 14). The scaphocerite in Crangopsis is more oval than in Kallidecthes. In Crangopsis thoracopod the precoxa and coxa are of similar length and the basis is slightly longer (Fig. 6); in Kallidecthes the precoxa and coxa appear to be shorter (Schram 1969). In Crangopsis the supposed gills on the pleopods are oval in outline and they are longer and more elaborate than in Kallidecthes.

Arrangement and closer morphological details of the aeschronectidan thoracopods has been so far known only in Kallidecthes richardsoni (Schram 1969, Watling et al. 2000). Although Peach (1908) described thoracopods also for Crangopsis socialis, his figures lack details. Similarly for the original material of Crangopsis eskdalensis (Peach, 1882), Schram (1979) noted that thoracopod remnants preserve no structural details. The present material documents very similar thoracopod arrangement and general morphology for both discussed genera. Crangopsis and Kallidecthes, thus, could represent sister taxa.

Occurrence. - Crangopsis socialis is known from the Mississippian of Scotland (Peach 1908, Schram 1979) and $C$. cf. socialis from Czech Republic (herein).

\section{Discussion}

Taphonomy. - Our specimen of Crangopsis is preserved laterally, which is quite typical for aeschronectid hoplocaridans (Peach 1908; Schram 1969, 1979; J.M. Schram \& F.R. Schram 1979). This implies relatively high profile and deep body for aeschronectids; thus, lateral preservation dominates in the fossil record. Although our specimen exhibits relatively well-preserved pleomeres, it does not appear to possess the complete shield. This can be a consequence of weak calcification of the shield, and hence a low potential 
for preservation in comparison with the pleon, or an indication that the specimen actually represents a moult. In aeschronectids from Scotland, the shield is usually well preserved (Peach 1908, Schram 1979). Moreover, moults of malacostracans may be difficult to distinguish in the fossil record (Bishop 1986, Jenner et al. 1998). Although for stomatopod moults a separated cephalothorax and pleon are typical (Reaka 1975, Mikulic 1990), "it is very difficult to distinguish moults from similarly oriented actual animals" (Jenner et al. 1998, p. 177). In our case, the head and thorax are not separated from the pleon, and the remains of the carapace are clearly visible only on its posterior aspect.

Whatever the case, the present specimen exhibits a relatively fine preservation of both the supposed gills, and the thoracopods, which is not common. Thoracopods seems to continue deep into the thoracic cavity, but what may appear as proximalmost leg elements are interpreted here as the thoracomere pleurites (Figs 5B, 6A).

If its identity is confirmed, the supposed mandible would be the first report on this structure preserved in aeschronectids. In fossil hoplocaridans, the undoubted mandibles have been reported in the basal Carboniferous stomatopods Gorgonophontes Schram, 1984 and Tyrannophontes Schram, 1969 by Schöllmann (2004) and Jenner et al. (1998), respectively; in the Jurassic sculdid stomatopod by Haug et al. (2010); and in Oratosquilla oratoria (de Haan, 1844) from the Pleistocene of Japan by Ando et al. (2013). Possible mandible imprints are known also in a sculdid larva from the Jurassic of Germany (Haug et al. 2008).

Thoracopod functional morphology. - The condition of the shield in our specimen from the Ostrava Formation allows us to describe the thoracopod morphology. Apparently, all members of Aeschronectida retained the ancestral state of similarly shaped thoracopods, whereas in modern mantis shrimp, thoracopods (sometimes referred to as maxillipeds) are diverse in form and function owing to a series of evolutionary changes (Haug et al. 2010). For Stomatopoda, four sub-similar-sized sub-chelate thoracopods seem to be apomorphic (Haug et al. 2010); these so-called raptorial appendages highlight the predatory life-style of all members of the group.

A different situation can be seen in aeschronectid hoplocaridans; here the appendages do not show any apparent structural adaptations, but rather exhibit simple thoracopod morphology. Nevertheless, there is one morphological aspect that may provide an insight into an aeschronectid life-style: the shortening of the posterior series of thoracopods. This character is present in Kallidecthidae and it can tell us something about normal posture of the animal during its life; assuming a benthic life-style (see below), longer thoracopods at the anterior part of cephalothorax point to an upraised thoracic posture. Similarly, modern stomatopods have raised anterior portion of the body. This adaptation seems to be bound on one hand with longer and more massive anterior thoracopods (raptorial appendages) and on the other with a predatory life-style since the upraised posture help the animal to have a better view of the surroundings. Interestingly, the elevated posture might have developed later in mantis shrimp evolution because no apparent size differences in thoracopods are observable in the more primitive Palaeozoic stomatopods (Jenner et al. 1998, Haug et al. 2010, Schram 2007). This could indicate that the upraised posture in hoplocaridans evolved separately at least twice, in stomatopods and kallidecthid aeschronectidans. A similar elevated posture occurred in Kallidecthes (Schram et al. 2013). Unfortunately, no data on thoracopod morphology are available for other members of Aeschronectida.

Life-style of Kallidecthidae. - For aeschronectid hoplocaridans several different life-styles have been suggested, such as nektonic, epibenthic, filter feeding (Schram 1986), detritus feeding (Briggs \& Clarkson 1990), or omnivory (Kunze 1981). The upraised posture is one feature that would make sense in animals with prevalent epibenthic life-style, thus we would argue for such a life-style for Kallidecthidae.

In stomatopods, the raising up the posture can be matched with the differentiation of thoracopods (maxillipeds) and the reduction of tergites, and hence the development of the predatory life-style. Linked with this, are the extreme specializations of visual acuity and the facilitation of elaborate agonistic behaviours so characteristic of mantis shrimp (Caldwell \& Dingle 1975, Marshall et al. 2007, Cronin et al. 2010, Schram et al. 2013). Upraised posture in stomatopods usually is not preserved in the fossil record; this is related to factors of taphonomy (Hof \& Briggs 1997). Similarly in kallidecthids, the upraised posture often has not been observed from the fossils themselves, but only inferred from thoracopod length, although several specimens of Kallidecthes richardsoni from the Mazon Creek biotas are preserved in life position (Schram 1969, fig. 112). For basal unipeltatans, opportunistic scavenging specialized in the handling of dead food has been suggested (Jenner et al. 1998); these taxa, however, possess sub-chelate thoracopods subequal in size and differ markedly from slender achelate limbs of Crangopsis and Kallidecthes. Detailed analysis of kallidecthid thoracopods with respect to functional morphology will be needed to resolve the issue of the life-style of these creatures.

Tagmatization in Aeschronectida. - As pointed out by Haug et al. (2012), significant changes in tagmatization within groups might mark the starting point for adaptive radiations. Haug et al. (2012) demonstrated this process in the stomatopod body plan and recognized altogether five tagmata in modern mantis shrimp; i.e., the sensorial unit, 

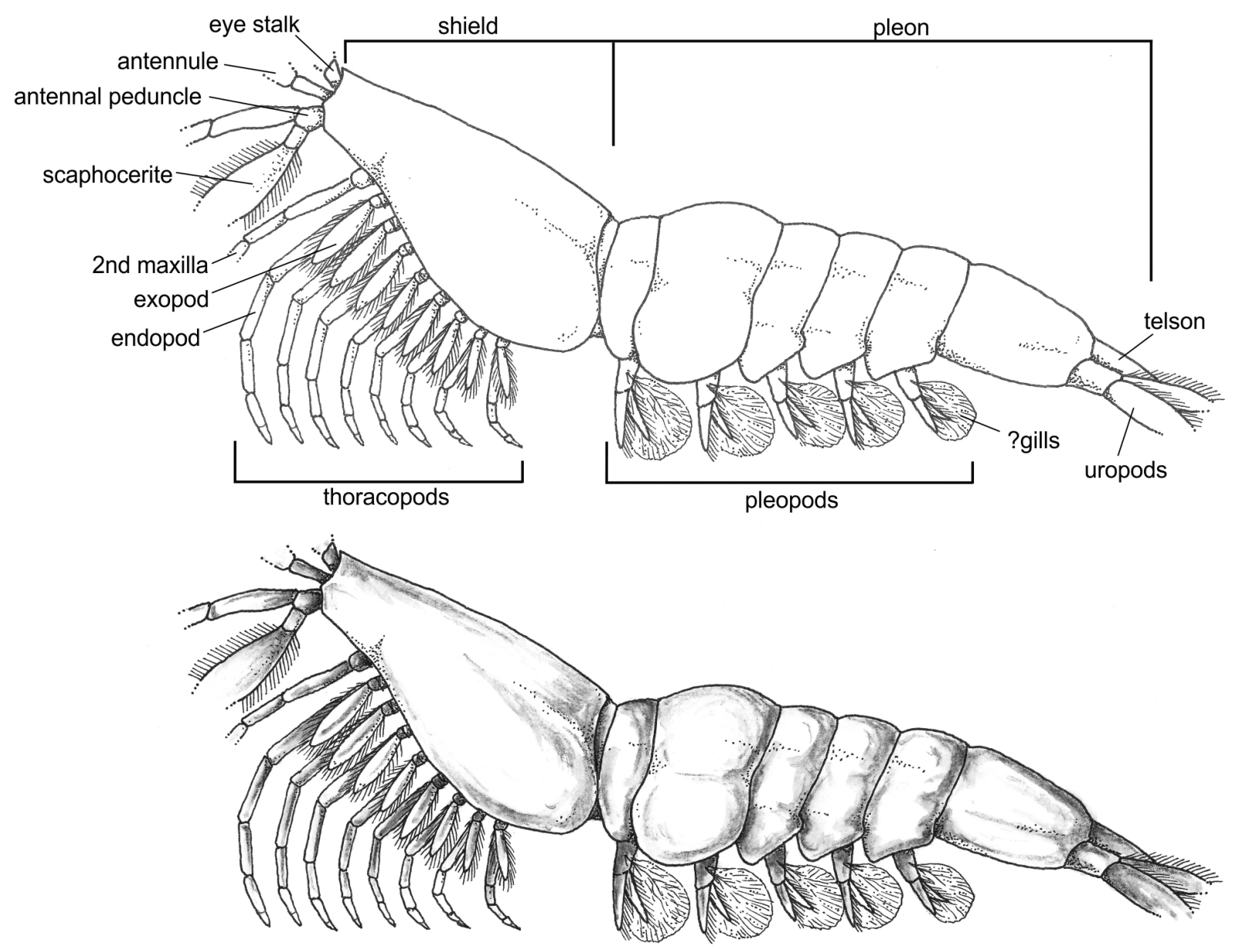

Figure 8. Crangopsis socialis (Salter, 1861), OM B 13970. Partial reconstruction. Note the upraised posture of the animal. Shield morphology is based on Schram (1979, fig. 9a) and Brooks (1969, fig. 155). The morphology of thoracopod exopods is conjectural.

the anterior food-processing unit, the posterior foodprocessing unit, the walking-appendage area, and the pleon plus tailfan. These units were recognized based on the following criteria: 1) dorsally or ventrally conjoined segments, 2) similar dorsal morphology, 3) similar appendage morphology, and 4) close spatial association of segments versus long distance to other segments. One can assume that for the stomatopods, the differentiation of the anterior food-processing unit from the posterior food-processing unit is the major tagmatic achievement. In the aeschronectids, clearly the cephalothoracic tagmatization was not as highly evolved in contrast to modern mantis shrimp; the food-processing units were not highly differentiated because of the fairly uniform thoracopod morphology. Based on the criteria 1 (segments conjoined dorsally with a shield), 3 (similar appendage morphology implying similar function), and 4 (close spatial association of segments), only four tagmata are evident at this point in the aeschronectid body plan. We should note, however, that tagma boundaries do not necessarily have to match segment boundaries (Haug et al. 2012). More studies using more- advanced methods (Haug et al. 2012 and references therein) are needed to resolve the issue of tagmatization in aeschronectid hoplocaridans.

\section{Conclusions}

From the data presented herein these conclusions can be made:

1) A single specimen of an aeschronectid hoplocaridan Crangopsis cf. socialis from the Mississippian of the Ostrava Formation (Czech Republic) is reported. It represents the first occurrence of Aeschronectida from continental Europe.

2) The studied specimen possesses all thoracopods allowing a more detailed description than heretofore available. Morphological similarities between the present material and its relative Kallidecthes richardsoni allows the reassignment of Crangopsis from Aratidecthidae to Kallidecthidae, 
leaving the former family with only its type genus Aratidecthes.

3) Thoracopod morphology of Crangopsis based on the present material suggests upraised posture of the animal during its life. We believe that the upraised posture developed independently at least two times within Hoplocarida, in Aeschronectida and Stomatopoda.

4) For Aeschronectida, we would divide the body into four tagmata: the sensorial unit, the food-processing unit, the walking-appendage area, and the pleon plus tailfan in contrast to five in Stomatopoda.

\section{Acknowledgements}

We thank Zdeněk Vašíček (Academy of Sciences of the Czech Republic, Ostrava-Poruba, Czech Republic) for encouraging at the beginning of the study. Constructive comments by two reviewers, Rodney M. Feldmann (Kent State University, Ohio, USA) and Joachim T. Haug (Ludwig-Maximilians-Universität München, Germany) improved significantly the manuscript. This work was supported by the Slovak Research and Development Agency under the contracts No. APVV-0640-10 and APVV-0436-12.

\section{References}

Ando, Y., Ugai, H., Kawano, S., Hirose, K., Nakatani, D., Kurosu, H. \& Karasawa, H. 2013. Unusual preservation of fossil mantis shrimp (Stomatopoda): occurrence of mandibles from the Pleistocene Ogushi Formation, Kyushu, Japan. Zootaxa 3691, 291-294. DOI 10.11646/zootaxa.3691.2.8

Bishop, G. 1986. Taphonomy of the North American decapods. Journal of Crustacean Biology 6, 326-355.

DOI $10.2307 / 1548174$

Briggs, D.E.G. \& Clarkson, E.N.K. 1990. The late Palaeozoic radiation of malacostracan crustaceans, 165-186. In TAYLOR, P.D. \& LaRwood, G.P. (eds) Major evolutionary radiations. Systematics Association Special Volume 42. Clarendon Press, Oxford.

Brooks, H.K. 1962. The Paleozoic Eumalacostraca of North America. Bulletin of American Paleontology 44(202), $163-338$.

Brooks, H.K. 1969. Eocarida, Syncarida, and Palaeostomatopoda, R332-R359, R533-R535. In Moore, R.C. (ed.) Treatise on Invertebrate Paleontology. Part $R$, Arthropoda 4. University of Kansas Press, Lawrence.

Caldwell, R.L. \& Dingle, H. 1975. Ecology and evolution of agonistic behaviour in stomatopods. Naturwissenschaften 62, 214-222. DOI 10.1007/BF00603166

Calman, W.T. 1904. On the classification of the Crustacea Malacostraca. Annals and Magazine of Natural History 7(13), 144-158.

Cronin, T.W., Porter, M.L., BoK, M.J., Wolf, J.B. \& Robinson, P.R. 2010. The molecular genetics and evolution of colour and polarisation vision in stomatopod crustaceans. Opthalmic \& Physiological Optics 30, 460-469.

DOI 10.1111/j.1475-1313.2010.00762.x

Dopita, M. \& Kumpera, O. 1993. Geology of the OstravaKarviná coalfield, Upper Silesian Basin, Czech Republic, and its influence on mining. International Journal of Coal Geology 23, 291-321. DOI 10.1016/0166-5162(93)90053-D

Gastaldo, R.A., PurkyŇová, E., ŠImÚNek, Z. \& Schmitz, M.D. 2009. Ecological persistence in the Late Mississippian (Serpukhovian, Namurian A) megafloral record of the Upper Silesian Basin, Czech Republic. Palaios 24, 336-350. DOI 10.2110/palo.2008.p08-084r

De HaAn, W. 1844. Stomatopoda. 220-225. In Von Siebold, P.F. (ed.) Fauna Japonica, sive description animalium, quae in iterne per Japoniam, jussu et auspiciis superiorum, qui summum in India Batavia Imperium tenent, suscepto, Annis 1823-1830 collegit, notis, observationibus et adumbrationibus ilustravit. Lugdunum Batavorum.

Haug, C., Sallam, W. S., Maas, A., Waloszek, D., Kutschera, V. \&. HAug, J.T. 2012. Tagmatization in Stomatopoda - reconsidering functional units of modern-day mantis shrimps (Verunipeltata, Hoplocarida) and implications for the interpretation of fossils. Frontiers in Zoology 9, 31.

DOI 10.1186/1742-9994-9-31

Haug, J.T., Haug, C. \& Ehrlich, M. 2008. First fossil stomatopod larva (Arthropoda: Crustacea) and a new way of documenting Solnhofen fossils (Upper Jurassic, Southern Germany). Palaeodiversity 1, 103-109. DOI 10.1186/1471-2148-10-290

Haug, J.T., Haug, C., MaAs, A., Kutschera, V. \& Waloszek, D. 2010. Evolution of mantis shrimps (Stomatopoda, Malacostraca) in the light of new Mesozoic fossils. BMC Evolutionary Biology 10, 290.

Haug, J.T., MaAs, A., Haug, C. \& Waloszek, D. 2013. Evolution of Crustacean Appendages, 34-73. In Watling, L. \& Thiel, M. (eds) The Natural History of the Crustacea. Vol. 1. Functional Morphology and Diversity of the Crustacea. Oxford University Press, Oxford.

Havlena, V. 1986. The cyclicity of the sediments of the OstravaKarviná coalfield. Časopis pro mineralogii a geologii 31, 337-352.

Hof, C.H.J. \& BRIGGS, D.E.G. 1997. Decay and mineralization of mantis shrimps (Stomatopoda: Crustacea) - a key to their fossil record. Palaios 12, 420-438. DOI 10.2307/3515381

JenNer, R.A.C., Hof, C.H.J. \& Schram, F.R. 1998. Palaeo- and archaeostomatopods (Hoplocarida, Crustacea) from the Bear Gulch Limestone, Mississippian (Namurian), of central Montana. Contributions to Zoology 67, 155-185.

KunZE, J.C. 1981. The functional morphology of stomatopod Crustacea. Philosophical Transactions of the Royal Society of London B 292, 255-328. DOI 10.1098/rstb.1981.0032

Lange, S. \& Schram, F.R. 1999. Crustacean evolution and phylogeny, 235-254. In Melic, A., De Haro, J.J., Mendez, M. \& RiberA, I. (eds) Evolucion y Filogenia de Arthropoda. Entomological Society of Aragon. Zaragoza.

LATREILLE, P.A. 1802-1803. Histoire naturelle, générale et particulière des Crustacés et des Insectes. 468 pp. F. Dufart, Paris.

Marshall, J., Cronin, T.W. \& Kleinlogel, S. 2007. Stomatopod eye structure and function: A review. Arthropod Struc- 
ture \& Development 36, 420-448.

DOI 10.1016/j.asd.2007.01.006

MiKuLIC, D.G. 1990. The arthropod fossil record: biologic and taphonomic controls on its composition, 1-23. In CULVER, S.J. (ed.) Arthropod paleobiology. Short courses in Paleontology 3. The Paleontological Society, Knoxville.

Peach, B.N. 1882. On some new Crustacea from the Lower Carboniferous rocks of Eskdale and Liddesdale. Proceedings of the Royal Society of Edinburgh 30, 73-91.

Peach, B.N. 1908. A monograph on the higher Crustacea of the Carboniferous rocks of Scotland. Memoirs of the Geological Survey of Great Britain, Palaeontology 1(1), 1-82.

REaKa, M.L. 1975. Molting in stomatopod crustaceans. I. Stages of the molt cycle, setagenesis, and morphology. Journal of Morphology 146, 55-80. DOI 10.1002/jmor.1051460104

Řeног̆, F. 1965. Neue Arten von Süsswassermuscheln aus Ostrava-Schichtenfolge. Věstník Ústředního ústavu geologického 40, 297-300.

ŘeHor̆, F. \& ŘEhořovÁ, M. 1972. Makrofauna uhlonosného karbonu československé části hornoslezské pánve. 136 pp. Profil, Ostrava.

SAlter, J.W. 1861. In Brown, T. Notes on the Mountain Limestone and Lower Carboniferous rocks of the Fifeshire coast from Burntisland to St. Andrews. Transactions of the Royal Society of Edinburgh 22, 385-404.

DOI $10.1017 /$ S0080456800030696

SALTER, J.W. 1863. On some fossil Crustacea from the Coal Measures and Devonian rocks of British North America. Quarterly Journal of the Geological Society, London 19, 75-80. DOI 10.1144/GSL.JGS.1863.019.01-02.14

SchöllmanN, L. 2004. Archaeostomatopodea (Malacostraca, Hoplocarida) aus dem Namur B (höheres Marsdenium, Karbon) von Hagen-Vorhalle (NRW, Deutschland) und eine Neudefinition einiger Arten der Familie Tyrannophontidae. Geologie und Paläontologie in Westfalen 62, 111-141.

SCHRAM, F.R. 1969. Some Middle Pennsylvanian Hoplocarida and their phylogenetic significance. Fieldiana, Geology 12, 235-289.

Schram, F.R. 1974. North American Paleozoic Peracarida. Fieldiana, Geology 33, 95-124.

Schram, F.R. 1979. British Carboniferous Malacostraca. Fieldiana, Geology 40, 1-129.

SCHRAM, F.R. 1983. Lower Carboniferous biota of Glencartholm,
Eskdale, Dumfriesshire, Scotland. Scottish Journal of Geology 19, 1-15. DOI 10.1144/sjg19010001

Schram, F.R. 1984. Upper Pennsylvanian arthropods from black shales of Iowa and Nebraska. Journal of Paleontology 58, 197-209.

Schram, F.R. 1986. Crustacea. 660 pp. Oxford University Press, New York.

SChram, F.R. 2007. Paleozoic proto-mantis shrimp revisited. Journal of Paleontology 81, 895-916.

DOI 10.1666/pleo05-075.1

Schram, F.R., Ahyong, S.T., Patek, S.N., Green, P.A., Rosario, M.V., BoK, M.J., Cronin, T.W., Mead Vetter, K., Caldwell, R.L., ScholtZ, G., Feller, K.D. \& Abelló, P. 2013. Subclass Hoplocarida Calman, 1904: Order Stomatopoda Latreille, 1817, 179-355. In von VAupel Klein, J.C. \& Schram, F.R. (eds) Treatise on Zoology - The Crustacea, Vol. 4A. Brill, Leiden.

SCHRAM, F.R. \& Horner, J. 1978. Crustacea of the Mississippian Bear Gulch Limestone of Central Montana. Journal of Paleontology 58, 394-406.

Schram, F.R. \& Schram, J.M. 1979. Some shrimp of the Madera Formation (Pennsylvanian) Manzanita Mountains, New Mexico. Journal of Paleontology 53, 169-174.

Schram, J.M. \& Schram, F.R. 1979. Joanellia lundi sp. nov. (Crustacea: Malacostraca) from the Mississippian Heath Shale of Central Montana. Transactions of the San Diego Society of Natural History 19(4), 53-56.

Špinar, Z., Čepek, P., BouČek, B., Eliášová-Frajová, H., Havlíček, V., Horný, R., Houša, V., Kalabis, V., Kukalová, J., Marek, L., Nekvasilová, O., Pokorný, V., Prokop, R., PŘIbYl, A., RƯŽIČKA, B., ŠnaJdR, M., ŠTemprokovÁ, D. \& ZiKMUNDOVÁ, J. 1965. Systematická paleontologie bezobratlých. 1049 pp. Academia, Praha.

ŠvaGRovsKÝ, J. 1976. Základy systematickej zoopaleontológie. I Evertebrata. 578 pp. Slovenské pedagogické nakladatel'stvo, Bratislava.

Walossek, D. 1993. The Upper Cambrian Rehbachiella kinnekullensis Müller, 1983, and the phylogeny of Branchiopoda and Crustacea. Fossils \& Strata 32, 1-202.

Watling, L., Hof, C.H.J. \& Schram, F.R. 2000. The place of the Hoplocarida in the malacostracan pantheon. Journal of Crustacean Biology 20, special number 2, 1-11. 